\title{
More Gas, Comrades! (Więcej gazu, Kameraden!)
}

\author{
Author: Krystian Piwowarski
}

First Published: 2012

\begin{abstract}
About the Author: Krystian Piwowarski was born in 1956. He graduated in Polish philology at the University of Silesia in Katowice. He is a journalist, playwright, novelist, and reporter in local media. He lives in Częstochowa.
\end{abstract}

Further Important Publications: Marlowe, Mann i Superman (1989, Marlowe, Mann and Superman; novel); Klaun (2012, The Clown; novel).

\section{Content and Interpretation}

The collection consists of fifteen stories about World War II and the Holocaust seen through the eyes of its perpetrators and accomplices. While an exact time and place are not given, most of the stories take place in Nazi-occupied Poland. Because it lacks a thoroughly prepared timeline, Piwowarski's literary representations seem disconnected from history, and the author plays liberally with the relationship between fact and fiction. In the afterword The Imperative of Remembrance, Piwowarski described his literary agenda with regard to the commemoration of the Holocaust. It arises, he argues, from a need to fill the gaps in fiction, which is unable to sufficiently grasp the issue of the Holocaust. What is needed in particular is to develop a perspective that approaches this issue from the outside, without recourse to direct experience. These beliefs are connected to the writer's concern about the general lack of knowledge concerning the Holocaust, and his ideas on how literature should be written in order for remembrance to continue (Piwowarski, 2012, pp. 267-269).

In the opening story Women in the Meadow and I, a Nazi gives air to his erotic fantasies. Train conductors in A Misunderstanding mock Jews who are dying while being transported to camps:

\footnotetext{
"So Stypka and Ratay dragged bodies into the steam engine. At first, they tried to throw them one by one into the furnace, but it was so high, and they were downstairs in the red snow, and even light girls with mouse tails bounced off the black oily sheet and fell on their necks. The corporal was impatient, the escorts were chattering, Dorsz moaned, holding his face, giving the corporal a look of reproach. The corporal praised the good work. He glanced at his watch. He asked when they would move. He looked at the material for the suits and did not say whether they were nice or not. The feet smoked, the corporal fumbled and groaned. He said that he must have cat fur on his knees because he had rheumatism”. (pp. 133-134)
}

Peasants in People and Jews promise to help the Jews they meet, who are nearly dead with exhaustion, only on the condition that they will be paid. According to Tomasz Mizerkiewicz: "The SS-men are still on family matters, like normal soldiers, they miss 
this or that beloved left behind at Heimat, they plot against their superiors, they make jokes to each other, they make friends and talk incessantly to relieve their boredom. It is no different for the Poles, who lie to their friends, steal Jewish property, flirt and drink" (Mizerkiewicz, 2013, p. 157).

Piwowarski reflects on borderline situations that illicit conflicting reactions from the reader, from a moral reluctance to engage with the material to denial and disagreement. The reader is unable to assess the position or indeed positions of the author, which appear by design to tangle and blur, to resist all efforts to make them clear. Some critics have expressed misgivings about an outsider who imitates the perspectives of the perpetrators, asking whether Piwowarski's work qualifies as Holocaust literature at all, or if an approach that draws so heavily on fiction should not be deemed inadequate to the task.

\section{Main Topics and Problems}

Favourable reviews of Piwowarski's stories, on the other hand, have praised his descriptions of the daily lives of perpetrators for their realism, as well as his ingenuity in illustrating Hannah Arendt's thesis about the banality of evil. In describing Piwowarski's view, Mizerkiewicz thinks of it rather as the evil of banality. Critics of More Gas, Comrades!, however, consider it as an example of the pornographication of the Holocaust, or as a form of Holocaust kitsch. Sławomir Buryła, meanwhile, describes the collection of stories as bizarre, criticising its lack of moderation and tendency towards extreme perversion, as in the episode where Jewish children are incinerated in a furnace, and the erotic observations of SS personnel in the extermination camps (Buryła, 2016, p. 101). Mizerkiewicz reminds us that the Holocaust requires an attitude of restraint, sometimes even silence, of the kind demonstrated by Piotr Szewc's novel $\rightarrow$ Annihilation. Yet Piwowarski wanted, first and foremost, to define the limits of the invention of the Polish witnesses to the Holocaust (Mizerkiewicz, 2013, p. 159), referring to the ambiguous stories of Tadeusz Borowski $\rightarrow$ Farewell to Maria. His main goal was to elucidate a certain tendency in the contemporary Polish imagination to insert oneself into the Holocaust as participant, and from that position to evaluate the society and social roles of an earlier time. If the author fails in this project, it is because he has not clearly delineated where his stories draw from the imagination and where from the historical past - it is on these terms, in any case, that his critics have denounced his immorality and inappropriate use of history. One may argue that the blurring of fact and fiction in More Gas, Comrades! has further resulted in a mixture of anti-Polish and antisemitic sentiment. While drawing on the model of such short stories as Farewell to Maria by Tadeusz Borowski and Professor Spanner by Zofia Nałkowska ( $\rightarrow$ Medallions), Piwowarski tends to simplify and muddy the gesture, and even while his aim may be to "re-write the Holocaust," in the words of James E. Young, Piwowarski's ethical and aesthetic missteps in More Gas, Comrades! tend to thwart his intention. The result, as his critics point out, is a work that shows ignorance towards the representation of victims. Contrary to the thoughts he ex- 
presses in the afterword, Polish literature has repeatedly addressed the Holocaust and in so doing created one of the richest collections of Holocaust stories in the world.

\section{Cited Works}

Buryła, S. (2016). Wokół Zagłady. Szkice o literaturze Holokaustu. Kraków: Universitas. Mizerkiewicz, T. (2013). Literatura obecna. Szkice o najnowszej prozie i krytyce. Kraków: Universitas. Piwowarski, K. (2012). Więcej gazu, Kameraden! Warszawa: W.A.B.

\section{Further References}

Tomczok, M. (2017). Czyja dzisiaj jest Zagłada? Retoryka - ideologia - popkultura. Warszawa: Wydawnictwo IBL PAN. Tomczok, M. (2019). Czy Polacy i Żydzi nienawidza się nawzajem? Literatura jako mediacja. Łódź: Wydawnictwo Uniwersytetu Łódzkiego.

MT 